Journal of Southern African Studies, 2017

Vol. 43, No. 6, 1255-1272, https://doi.org/10.1080/03057070.2017.1381908

\title{
The Micro-History of a South African Murder
}

Jeremy Krikler

(University of Essex)

\begin{abstract}
This article explores a murder that took place on a Transvaal farm in the early 20th century. By subjecting it to the techniques of micro-history, it demonstrates that the killing, far from having merely a narrow personal or criminal significance, casts a powerful if lurid light on important historical processes and phenomena. Central among these are the following: the social power of Boer landowners over an impoverished white tenantry; the intimacy and violence of master-servant relations between the races in the countryside; the new mode of policing in the wake of the South African War; and the fact that black action in that conflict continued to affright Boer/Afrikaner consciousness. In short, the article offers a study of how a wider history is embedded in, and illuminated by, a single criminal case. The startling evidence of the trial is also used to convey the relationships of power on a particular agrarian estate, and how these were challenged as the state enlisted servants as witnesses against their masters.
\end{abstract}

Nicholas van Rensburg was killed like a sheep. Of that there is no doubt. His throat may have appeared to one policeman to have merely been slit 'from ear to ear', but evidence arising from the autopsy disclosed something more practised: 'two incisions had been made on the throat, and both carotid arteries and [the] jugular vein [had been] severed'. ' Exploration of the wound found that the way in which 'the throat had been stuck' was 'exactly the same' as a slaughtered sheep. ${ }^{2}$ But whoever murdered Van Rensburg had tried to make his death look like suicide: his own knife had been used in the deed and it had been placed in his lifeless hand. ${ }^{3}$ But there were problems with the notion of suicide. First, how could a man slit his throat, sever one after another the giant blood vessels of the neck, and not only not lie in a pool of blood but apparently have no blood on his clothes at all? How is it that the only blood stains where the body lay were on the blade of the knife and on the hand that clutched it? And why is it that there were 'traces of fresh blood ... about 500 yards from where the body was found' and that they 'extended about 50 yards in a straight line, in patches, at intervals of about a yard'. ${ }^{4}$ Finally, how could a man have the equanimity to place his hat over his face after cutting his throat?

The idea of suicide be damned, this was murder. Its victim was a poor man whose demise was seemingly of no historical significance whatever. But the closest attention to the evidence emerging from the killing suggests something else: a way into the frightening exercise of power on a South African farm in the early 20th century, an exemplification of the results of historic processes of impoverishment among rural whites, an illumination of the emergence of a more far-reaching and procedure-bound (but also contested) mode of policing after the South African War, a case study of how race could shape legal outcome at this time. And, beyond this, the case allows us to glimpse briefly, like sparks dying in the night, some dramatic resonances of a recent war and the intimacies of master-servant relations. In short, this murder cries out for micro-history, with its characteristic 
combination of an intense focus on 'individual lives and events' and the proof of how these 'reveal more general phenomena'. ${ }^{5}$ In fact, it is only through micro-history - by reconstructing this individual event in all its detail - that the general significances emerge. History written on a larger scale, with its own demands and strictures, will have a tendency to absorb merely as fleeting evidence ('a simple footnote', in Carlo Ginzburg's terms) a case that might glint with riches if explored on a different scale. ${ }^{6}$ Significantly, the case considered here could find no place - not even that of the simple footnote - in a general monograph on agrarian relations, during the research for which it was happened upon. ${ }^{7}$ But by adopting the fundamental technique of micro-history - that is, by 'reducing the scale of observation', and by aiming at 'a microscopic analysis ... of the documentary material' an incident can now be wrung for manifold significances. ${ }^{8}$

But, first, the killing that set the case in motion. It occurred in January 1903, a few hundred kilometres south-east of Johannesburg, on 'Rooipoort', a farm very close to the town of Volksrust, which lay in the Wakkerstroom district of the Transvaal colony. It is a district whose landscape, often rimmed by gently sloping hills, is tawny in dry seasons but takes on an aspect of green and lovely peace in the rainy season, the season of the murder of Nicholas van Rensburg.

\section{Perpetrators and Witnesses}

If we build up an account of the murder from the testimony of the black servants, it would run like this. On the fateful day, the murderer of Van Rensburg had determined to get the man drunk. Van Rensburg was in the house of Gil (or Gideon) Visagie at some kind of drinking party. ${ }^{9}$ But it was clearly a party in which some of the participants were holding back while they plied Van Rensburg with large doses of alcohol. One of the servants, Jacob, who was present in the kitchen of Visagie's house for about an hour, remembered that Van Rensburg was 'very drunk - quite helpless', so much so that when he rose from his chair he looked as if he would topple over. All his fellow drinkers and some of the servants laughed at his state, but Jacob noted something extraordinary: while Van Rensburg was thoroughly inebriated, the other drinkers were not and yet 'they were seemingly pretending to be drunk'. ${ }^{10}$ Another servant, Isaac, remembered how 'Van Rensburg's drinks were always given to him neat' but that 'the others all put water into theirs'. Even when Van Rensburg called for water, the man who would kill him tried to get him to take gin. ${ }^{11}$ After a while, Van Rensburg - whose house was on Visagie's farm - wanted to leave for home, but the drink had done its work: in making for the door 'he was so unsteady that he fell flat on the ground tumbling over a chair'. Visagie helped him up. Ominously, the other two men in the drinking party - Carl Landman and Hans Visagie - left the house and waited at a point some distance away. Shortly afterwards, so did Gil Visagie, steering and supporting Van Rensburg, who 'was staggering very much'. In the darkness, they did the deed. Landman and Hans Visagie held the unfortunate man in place, while Gil Visagie grabbed him by the hair 'drew back his head and cut Van Rensburg's throat'. The body was then taken away from the place of the killing (it was evidently too close to Gil Visagie's house) and deposited - hat on face, knife in hand - by a wall. ${ }^{12}$ 
This is the murder as described by the servant Isaac in his sworn affidavit of 20 August 1904.

According to that version of events, initially unbeknown to the murderers, Isaac had merely witnessed the killing, having come across it on his way 'to fetch water'. ${ }^{13}$ However, at the murder trial itself, which was held the following year, Isaac's evidence before the court suggested something else. Isaac spoke now of having being ordered by Visagie 'to hold the bucket under Van Rensburg's neck'. He did so and, so he said, 'caught about half a bucket of blood' as the man's life literally ebbed away. One of the accomplices - Landman - then evidently decanted the blood into a nearby stream. ${ }^{14}$ Isaac here transmutes himself from observer in the night to accomplice in murder. Since he could gain nothing - indeed, he could potentially endanger himself - by offering this testimony, we can consider it fact. And once we do so, the power of a particular kind of social relationship on a South African farm becomes manifest. It suggests that Visagie felt confident enough of his power over Isaac for him to do his bidding, but it also suggests a degree of trust - involving him in the most dangerous action - that we have to explain.

Isaac, as we shall see, would have been just the kind of servant who might be roped into the murder. The Transvaal farm in the early 20th century could contain a number of black labourers and white tenants, and this was the case with Visagie's Rooipoort. Some of the labourers would have been drawn from black peasant households for defined periods of labour service - there is a hint of this in testimony (soon to be provided) of one of Visagie's servants. But there would have been other workers who fell into a different category entirely. ${ }^{15}$ They were enmeshed in the white household to an extraordinary degree. And this would have been the case with Isaac. Consider his self-description:

I was a small boy when I first went to Gil Visagie's farm.... My parents are all dead.... Before my father died he gave me to Gil Visagie. I worked for him chiefly in the house and in the stables. I also helped to do the ploughing. I know practically everything that goes on in Gil Visagie's house as I have nearly all the kitchen work to do. I am always in and out of the house. When people come to the house I am called to either take the horse or bring coffee. ${ }^{16}$

This was a servant, then, who was strongly connected to his master and whose original familial nexus seems to have been definitively broken, first through some kind of transaction between his father and his master - 'my father ... gave me to Gil Visagie' - and then through the death of his parents. According to Isaac, the transaction would have taken place in the $1890 \mathrm{~s} .{ }^{17}$ Isaac, then, was a member of that distinctive servile class - it tended to be acculturated in Boer households - that had been driven or sold into the service of white farmers. There were a number of routes into such service: they included Boer raids and demands upon African societies; and purchases of children (often through goods) from African communities that had themselves captured children in conflict with other Africans. ${ }^{18}$ It is held that such modes of acquiring captives of a very young age declined notably in the last decades of the 19th century. ${ }^{19}$ The experience of Isaac, who had been given over to a white landowner in the 1890s, probably for some resource or other, suggests that we might look at another mode by which children entered Boer households as permanent servants: through an individual exchange with the head of an impoverished, marginalised African family. The advent of British rule after the South African War would have reduced the space for all such practices, but we should not imagine, given the pre-existing culture of the forcible absorption of youths into Boer households and 
enterprises, that they did not find a place in the margins of the new order. In the early 20th century, the Government Native Labour Bureau of the colonial state became concerned by evidence that youths, described as '[p]robably undersized' for labour on the mines, were being 'hawked' by a labour agent to Boer farmers, 'bought' by them, 'bound to them for an indefinite period' and denied wages. ${ }^{20}$ It is possible that this was a shadow of earlier practices. With regard to Isaac, it is clear that the route that he took into the world of Gil Visagie would have locked him into the household in a subordinate but nevertheless intimate way. It should not be surprising, then, that some gin had been given to him during the general drinking on the day of the murder. ${ }^{21}$ Most farm labourers would most certainly not have been included in such revelry. Indeed, there appears to have been only one other servant who was treated to this and, like Isaac, he had been so assimilated into a kind of servant-wing of the Visagie family that he referred to himself as having been 'brought up by Gil Rooipont Visagie's father'. ${ }^{22}$ It was precisely people like this, servants with whom masters had long and exceptionally close relations, who were so trusted that when the Anglo-Boer War broke out, they were tasked to accompany their masters in battle. ${ }^{23}$ As is suggested here, they could be tasked to undertake other duties, such as facilitating a killing.

Would there be some reward for Isaac's loyal service and for his keeping silent about what had happened? In his evidence - both in his initial affidavit, where he did not refer to his role in catching the blood, and in his later testimony before court, where he did - he spoke of his master promising him 10 head of cattle. In the later evidence the 10 head of cattle were supplemented with a death threat if he did not assist at the murder. ${ }^{24}$ However, we should take the death threat in the later evidence as Isaac's invention to justify his role before the court: rewards and bribes are not usually offered at precisely the same moment as extreme intimidation. What the 10 head of cattle represented was Visagie's gratitude. To a different kind of servant, one not enmeshed in the family in the way in which Isaac was, the power of the master could be enforced simply through a death threat.

We can see this in the evidence of Velapi, a female servant - I am unable to determine her age: she is referred to as 'the Native Girl' by a policeman at a time when white authority would refer to all black females of whatever age as girls. ${ }^{25}$ Velapi - sometimes referred to as Vilopi or Filapi - appears to have been somebody who undertook periodic labour service for Visagie. This would account for her referring to the fact that, at the time of the murder, she 'had only another six days to work'. According to her testimony, she was returning from collecting water - there was a stream not far from the house - when she came across Van Rensburg being held down, though she stated that she did not see the actual murder itself. Later, 'Gil Visagie came into the kitchen and told me I must say nothing about this [;] if I did say anything he would kill me. He said he would cut my throat. I said I will not say anything.... I was frightened and did not sleep that night .... The next day, when Van Rensburg's body was discovered, she was certain that it was related to 'the act I saw committed by Hans Visagie[,] Gil Visagie and Karl Landman the previous night'. Velapi, however, had been sufficiently intimidated. When the initial investigations took place, she kept schtum: "[t]he reason of my not stating the true 
facts of the murder of van Rensburg is because I was afraid as Gil Visagie told me on the night of the murder that if I said anything to anyone about it he would kill me'. ${ }^{26}$

This evidence suggests the immense power of intimidation of this South African master, lord of his domain. But it also suggests that the relations between the master and one kind of servant dictated the way this power was exercised. In the case of the female Velapi, it is likely that a number of factors - her sex, her episodic labour for the landlord, the likely dependence of her family on land provided by him, the fact that there was no deep connection between her and Gil Visagie - saw the landlord exercise his power simply through brute intimidation. In the case of Isaac, who had continuously been working for Visagie since his childhood, who was embedded in the household and with whom there was a close connection, the power was asserted differently. Given the level of trust but also the power of the master over him, he could be tasked to assist at the murder. After that, a reward (10 cattle) could be promised. But, just to make sure of matters, Isaac was 'sent away' in the period during which the initial investigation took place. ${ }^{27}$

But what would happen when he returned, this trusted servant who had witnessed his master cutting the throat of Van Rensburg, and who knew that the police were trying to work out who was responsible for the man's demise? On some of the evidence provided, it seems that the circumstances now worked to transform the world of master and servant as they existed between Isaac and Visagie. Orders seem no longer to be followed in quite the same way. Perhaps extra favours were now expected. Could the servant sometimes play the master? Certainly, something extraordinary appears to have happened on the farm before Visagie was formally arraigned. He was said to have commented to a local schoolmaster that Isaac would 'not obey his orders any more'; one of the farm workers spoke of Isaac knowing 'all about the murder' but that he was 'to[o] cunning to say anything, as he has such a good time with G Visagie'. Described as having become 'a petted Member of Visagie[']s family', somebody who did 'as he likes', Isaac was spoken of by a detective sergeant masquerading as a druggist's agent as being 'practically Boss over Gideon Visagie of which I have had ocular proof myself.. ${ }^{28}$

This evidence suggests, then, that some kind of intimate reversal of power had taken place, although we should be careful not to overstate it, as did the detective sergeant. This kind of reversal was beyond the power of Velapi: she would soon enough return to her peasant household, the head of which would have expected and demanded that his access to land not be disrupted through any trouble with the landlord; she was not embedded in the household in the same way as Isaac was and, subject merely to a regime of intimidation and command, she would not have had the space to engineer the kind of transformation that Isaac, however briefly, seemed to manage. In part, what gave Isaac power was his enmeshment with Visagie's family.

As was suggested in the account of the murder provided above, it was not only the black servant Isaac who assisted Gil Visagie in the murder. There were two whites as well: Hans Visagie and Carl 
Landman. A notable feature of Gil Visagie's farm, Rooipoort, in 1903 was the degree to which it made use of white labourers. In the wake of the South African War of 1899-1902, there was an acute scarcity of black labour in the Transvaal generally and significant numbers of whites with limited economic options. ${ }^{29}$ More than once in testimony relating to the case, one comes across evidence of white men employed by Visagie: men like the nervous Mathys Grove, whom Visagie ordered into town to report the tragedy and for whom the murder seemed somehow related to ghosts and 'strange lights' ${ }^{30}$ or those whites used in work on a dam on the farm. ${ }^{31}$ In restoring production after the South African War, it was probably necessary for a landowner like Gil Visagie to draw on what labour he could muster. Inevitably, this became enmeshed with kin connections and obligations, not least because, in Boer agrarian development, the rise of the relatively powerful landowner was frequently linked to the impoverishment of relatives linked to him.

The classic analysis of the origins of poor whites in rural South Africa, that by William Macmillan, noted how there could be a familial connection between landowners and their landless white tenants. It was a long, complex history that had led to the impoverishment of many. There was the ending of the possibility of colonising new lands, the impact of war and the commercialisation of agriculture, a complex interaction between inheritance practices and the creation of marginal farmers whose lands were gobbled up by the better-placed. The marginal then became landless and could become the dependants of their landed relatives. ${ }^{32}$ It is quite obvious - and whatever the presence or order of each of the particular forces sketched above in making this possible - that the extended kin network of the Visagies was marked by this phenomenon. It was certainly witnessed to some degree on Visagie's farm, Rooipoort.

Gideon - he was more familiarly known as Gil - Visagie was a man who clearly stood at the apex of social and economic power in his extended family and he was accustomed to the loyalty and deference of lowlier relatives. This is why they could be tasked with the most extraordinary requests: when, in late 1902, a cousin of his sought a loan, he had actually been asked by Visagie to kill Van Rensburg for him. ${ }^{33}$ Indeed, the murder of Van Rensburg, if we accept the testimony of the black servants, saw him mobilise the poor white dependants who lived on his farm. According to that testimony, his accomplices were his brother, C.J. (known as Hans) Visagie and Carl Landman, who was his brother-in-law. That they were poor is beyond dispute. According to a brother of his, 'C.J. Visagie was a poor man and had no property.... He had always been poor'. As for Landman, he 'had no landed property' and merely 'a little stock'. ${ }^{34}$ The degree of power that Gil Visagie exercised over these men, particularly his brother Hans, is suggested by compelling evidence, not least the fact that their families lived on his land; indeed, Hans was described as 'a poor dependent' [sic] of his brother, a man who 'would do anything' for Visagie: 'his brother's slave'. ${ }^{35}$ The kind of man who could be prevailed upon to assist in a murder.

As for Landman, there is even some evidence that his participation in the murder may have been impelled by his desire to escape poor white status. Landownership was crucial to this, and we find 
that shortly before the murder somebody had put this dream nearly within reach. In the month in which the murder took place, Landman 'had spreed in town' with his fellow accused. What Landman and Gil and Hans Visagie discussed in the midst of their revelry, we cannot know. But what we do know is that Landman arrived back home from Volksrust with 'a large sum' ${ }^{36}$ Just after the murder, he was able to purchase 'part of a farm', though he was able to put only $£ 50$ towards this, and his hopes of landownership were to fail: in October 1904, when he was brought to court for the preparatory examination on a charge of murder, he was described as landless. ${ }^{37}$ There is nevertheless something suspiciously suggestive of the pattern of events. Shortly before the murder, Landman meets in Volksrust with the other two men accused of killing Van Rensburg; they happily consort with Bacchus; Landman returns home with a good deal of money; Van Rensburg is murdered; Landman immediately puts money down on land. Blood money from Gil Visagie?

If one were to provide a social hierarchy regarding those involved in the murder, the master and landowner - the man who wielded the knife - would obviously be at the apex; Landman, a man apparently descending into poor white-ism would be next, followed by Hans, poverty stricken and at the command of his brother; and then the black servant, Isaac. There was more class kinship between Hans and Isaac than either of them realised: perhaps this is why, on the day of the murder, it was Hans who gave gin to Isaac in the general drinking on that day. ${ }^{38}$ So low was Hans in the white hierarchy of the farm that he could have difficulty in compelling the obedience of a black worker. Thus Willem, one of Gil Visagie's labourers, recalled being asked by Hans Visagie 'to take some fresh killed mutton home for him'. But Willem would not. ${ }^{39}$ We should take this as emblematic of a black worker's sense of Hans' place in the social structure.

For men like Hans Visagie and Carl Landman, dependence on their powerful and propertied relative was central to their being enlisted in something nefarious. But we should not imagine that this somehow wiped away either the bitterness they felt at their position, their material insecurity, or their antagonism to one who held power over them. It is surely significant that, even after the murder, they were said to have stolen pigs from Gil Visagie; that the poor Hans had on one occasion said that he did not care if his brother was executed; and that the cousin whom Visagie originally tried to get to murder Van Rensburg was evidently happy to give evidence against him. ${ }^{40}$ All this bespeaks a kind of muffled hatred.

\section{The Motive and the Victim}

If Visagie lorded it over his brother Hans and his brother-in-law Landman, he exercised a terrible power over Van Rensburg, the man whom he would murder and whose wife was his lover. We do not know when the love affair began, but it was clearly discernible during the recent South African War, in which Van Rensburg fought and was taken prisoner by the British. ${ }^{41}$ During this time, his wife was either in the town of Volksrust (very near Visagie's farm) or an inmate of the local British concentration camp, 'the Volksrust burgher camp', as it was known. Visagie seems to have had a certain freedom during this period, a suggestion that he had either not joined the Boer forces or that he had 
surrendered to the British. He arranged for purchases to be made on his lover's behalf, provided her with money, and was 'often' seen at the burgher camp where he was described as 'very intimate' with Van Rensburg's wife; he had slept in her tent and she was seen on his lap. In that period of the war when Van Rensburg's wife had lived in the town of Volksrust, Visagie was said to have been at her house 'at all hours of the day', to have bought her jewellery and to have been seen 'massaging her'. ${ }^{42}$ Visagie began to wonder what the penalty for adultery would be. ${ }^{43}$

When Van Rensburg returned from the war, his poverty was such that he clearly had no choice but to live on Visagie's farm, with his house (and his wife) very close - a mere half-mile, said the police from the landowner's. ${ }^{44}$ Quite simply, he was profoundly undermined as a man. Among Boers in the countryside, landlessness corroded the status of the male head of a household like nothing else, ${ }^{45}$ and this was compounded in Van Rensburg's case by his losing his wife to the landlord. The poor man's lack of resources and his dependence on his wife's lover were to be confirmed on his death, when his widow received what she described as 'nothing' from Van Rensburg's estate: the only money and goods that came to her were through a promissory note given to Van Rensburg by Visagie for some livestock. ${ }^{46}$ Significantly, the note had been issued very shortly before his murder, and it seems that Van Rensburg saw it as his ticket out of an intolerable situation: it was said that he was planning to leave the area - the children would have to come with him - because of the relationship between Visagie and his wife. ${ }^{47}$ By then Van Rensburg had come to blows with the landowner over the affair and had warned Visagie that he should 'not think [that] he was going to establish a brothel' on the farm as he had in Volksrust. The aggrieved man was also more than hinting at violence against his wife. Visagie, meanwhile, was infuriated by his tenant's accusations and worried that he might be brought before the church elders because of them. ${ }^{48} \mathrm{He}$ had much to fear in this regard. The elders were decisive figures in the congregations of the Dutch Reformed Church and they called upon the homes of members and monitored family affairs. With the authority to investigate misdemeanours, they also had the power to refer miscreants to the local Church Council, which could publicly humiliate and excommunicate the unrepentant. ${ }^{49}$ By the time of the murder, then, Visagie had felt the fists of Van Rensburg, who feared the denunciation of his behaviour to the church.

Given the calculation and pre-meditation involved, it is hard to call the murder a crime of passion, but Visagie had an undeniable yearning for Van Rensburg's wife. Significantly, much of our knowledge of the romance on the farm comes from the African servants. It suggests that the confidence of Visagie in his power as a master was such that he had no qualms about failing to conceal his affair from them. When, during the South African War, his affair commenced, he had actually sent a servant to live in Volksrust to help his lover: on one occasion, the servant brought in the morning coffee to find them in bed. The detailed knowledge of the affair on the part of the workers on the farm bespoke both the intimacy of life on a farm and also the ability of whites to act and speak in front of black servants as if they were of no account. Before one servant, Visagie had signalled to his lover with a mirror - it was referred to as 'heliographing' - when leaving the farm for town on a particular day. The servant, Rose, 
'a native girl working for Koos van der Merwe', one of the white tenants on the farm, seems to have been tasked by Visagie with taking gifts to his lover with the instruction that this be kept from his (Visagie's) wife. Another servant, Clara, remembered the recurring rows between Visagie and his wife over the affair: she had been present when Visagie's wife had asked him what it was about his lover that led him 'to prefer her to his wife'. ${ }^{50}$ Yet another servant recalled happening upon a fight between Visagie and Van Rensburg: he was later told (surely by another servant who had been present) that Van Rensburg had said to his tormentor: 'you are whoring with my wife. ${ }^{51}$ There is a sense in which Visagie's perpetration of the murder in front of Isaac was the most extreme expression of the master's nonchalance about the presence of servants while the intimate drama of his life unfolded.

It was this nonchalance and what the servants witnessed because of it that was to put Visagie's life in danger. Interestingly, the police clearly saw the servants as a key to unlocking the case. They also knew, however, that so long as Visagie's power was exercised over the residents of the farm, their inquiries would be stymied. Indeed, their first investigation collapsed; they had accused Visagie of murder, but apparently could not get adequate evidence for him to be formally charged. ${ }^{52} \mathrm{He}$ duly repaired to a Volksrust bar to boast of the police's failure. ${ }^{53}$ In the ensuing year, he seemed untouchable. For a detective involved in the inquiry, it was obvious that the key witnesses had to be isolated from his world before evidence would be forthcoming. Things were 'impossible owing to his [Isaac's] relations with Visagie', he remarked. But the detective had worked out a way forward, one that hinged upon exploiting the state's mechanisms of the racial control of movement. Aware that Isaac did not have a 'regulation pass', he proposed that he 'be arrested on his coming to Volksrust': '[o]nce inside we can deal with him'. A spy would be put into prison with him and the necessary information elicited. ${ }^{54}$ As for 'the Native Girl Velopie', she was duly 'arrested as being an accessory after the fact'. The investigating detective spent five hours with her until late into the night and duly reported that she was 'now only to[o] willing to divulge every thing she knows'. ${ }^{55}$ This would have been quite impossible had she not been isolated from Visagie, a man who had threatened her with death if she spoke of what she knew about the murder. In the end, the key evidence brought before the courts came from Isaac and Velapi/Filapi.

\section{Why the Case was Lost}

At the preliminary hearing in 1904, even a lawyer for the defence conceded that 'the weight' lay on the side of the prosecution, while a police officer implied that he would be astounded if 'any defence' could prevent a guilty verdict for what was, in his judgement, 'one of the most brutal, callous, cold blooded, calculating murders ever conceived' ${ }^{56}$ But when the formal murder trial was held the following year, those accused of murder were acquitted. There were several reasons for this.

It will be remembered that both Isaac and Velapi referred to three white men engaged in the killing: Gil Visagie, who cut Van Rensburg's throat, and Carl Landman and Hans Visagie, who held him while this was done. Part of the defence strategy was to prove that this gang did not exist by asserting that Carl Landman, whose family lived on the farm, was away at the time. The trouble for Landman was 
that his story was called into question by affidavits from his stepdaughters, Helena and Wilhelmina van Rensburg. (They had their own trauma to endure, given that their stepfather and mother had been tried - unsuccessfully - for the murder of their father in the early 1890s, after which the couple had married. Bizarrely, the man killed then was the brother of the Van Rensburg whose murder is the focus of this study. ${ }^{57}$ Landman's stepdaughters swore that they eavesdropped on a conversation between him and their mother. 'Look here', he had said,

I am afraid that these children can make a declaration that they heard me coming to the house that night.... Mother replied 'No, Wilhelmina has already made her statement in which she stated that father [that is, stepfather] was not at the house that night'. Father replied you swore at me in front of the kaffir girls and said I had killed both Nicholas ... and this Van Rensburg. Mother replied 'Och, they can do nothing, I shall say that I was angry. ${ }^{58}$

Not surprisingly, Landman worried about being 'strung up' on account of his wife 'opening her mouth too wide'. ${ }^{59}$ After Landman's arrest, there followed a tussle between the police, anxious to place the evidence of the stepdaughters before the court, and Landman's wife, desperate to suppress it. The police recognised how crucial this evidence was and also the necessity of isolating those giving it from their fearsome mother: 'the difficulty', one police officer remarked with respect to Helena (or Lena), one of the daughters, was 'to get her away from her mother', somebody who was 'as suspicious as the devil' and who was held to have the power to 'persuade her [daughter] to say exactly what she wishes her to, \& entirely contrary to facts'. Mrs Landman - we never learn her first name in the documents - emerges as a sinister woman of whom her daughter was 'dreadfully afraid'. 60

Nevertheless, some time in 1904, Landman's stepdaughters managed to leave Gil Visagie's farm and were residing in the town of Volksrust. At the preparatory examination of the accused, which took place in late 1904, both Helena and her sister took the stand and provided evidence that called into question their stepfather's insistence that he was not on the farm on the night of the murder. It was not that they testified to having seen him; it was rather their evidence of what they had overheard him tell their mother that was crucial. As Wilhemina told the court, Landman had said not only that 'he was afraid the children had seen him return on the night Van Rensburg was murdered', he feared too that 'the Kaffir maid had seen him when he and C.J. Visagie [the other accomplice in murder] climbed over the wall'. ${ }^{61}$

Once such evidence had been sworn before police or in court at the preparatory examination, Landman's wife - she was Gil Visagie's sister - did all she could to have it retracted by her daughters. A particularly chilling moment in the proceedings at the preparatory examination was the point at which the magistrate decreed, against the wishes of the prosecution, that Helena and Wilhelmina 'be returned to the custody of their mother' as they were technically minors. ${ }^{62}$ Helena was about 18 , Wilhelmina a little older, it appears, and both young women evidently managed to get (or stay) away from Rooipoort farm. ${ }^{63}$ As we shall see, however, they proved unable to avoid the brutal threats of their mother. Even at the preparatory examination in October 1904, Helena spoke of her mother threatening to 'give her sister a beating if she gave evidence against Landman' and warning her, 
Helena, 'that she also must not do so'. ${ }^{64}$ Once Helena had gone before the court at the preparatory examination, her mother was threatening to 'tie a rope around ... [her] neck and hang her up to a beam with her toes touching the ground for an hour every day as punishment'. ${ }^{65}$ This sounds remarkably like a punishment evoked in Steve McQueen's film of Twelve Years A Slave. ${ }^{66}$ In fact, 'slow strangulation' had originally been one of the direst punishments inflicted upon slaves in the Dutch period in South Africa. ${ }^{67}$ At any rate, Mrs Landman's threat to her daughter was so specific that one wonders if a shadow of the earlier brutal practice darkened the world of the farming family to which she belonged. We have to account somehow for the particular form of torture that she was proposing. Perhaps she was familiar with it from what had been inflicted on black farm workers who had flouted the Visagies' authority in the most challenging way.

After the preparatory examination and before the full murder trial, the ruthless, vigilant and energetic Mrs Landman contrived access to her daughters and waged an unremitting campaign of intimidation and emotional blackmail. Both Wilhelmina and Helena confirmed that their mother had asked them to testify that their evidence against Landman was false, the result of bribery by Detective Bullock. She issued the most violent threats against Helena: she would bind her up and beat her in front of the police 'and show them who is the boss': 'on your evidence', she warned, 'three men's lives' were 'hanging by a short thread', but the thread by which Helena's life was hanging was 'still shorter' ${ }^{68}$ So extreme was the situation in which Helena was placed that she came close to suicide; Wilhelmina, meanwhile, was clearly ostracised by the wider family. The withdrawal of her original evidence by stating that it was pressed on her by the police was, she was told, the only way in which she could be accepted once more by her relatives. ${ }^{69}$

Mrs Landman won out in the end. Neither Helena nor Wilhelmina gave evidence in the murder trial at the Supreme Court in Pretoria. Hence key evidence could not be put before the court. It was, of course, beyond the power of Mrs Landman to prevent her daughters from being called before the court. The police and prosecution themselves decided on this for reasons that were linked to Mrs Landman's activism but which have a bearing on a particular historical context. To understand it fully, we must take a detour into the transformation of policing in the Transvaal in the early 20th century.

Under Kruger's South African Republic - the Boer state that was defeated by the British and was converted into the Transvaal Colony in the early 20th century - the police (the South African Republic Police, known as the ZARPs) were notoriously corrupt and inefficient. ${ }^{70}$ In the imperial propaganda in the run-up to the second Anglo-Boer War, they were also portrayed as high-handed and oppressive in their treatment of British subjects. ${ }^{71}$ The displacement of the ZARPs and the creation by the British of the South African Constabulary (SAC), a highly professional police force, was seen as essential and can be considered as a symbol of the transition to a modern state during this period. ${ }^{72}$ The SAC had a notable rural focus, and Joseph Chamberlain, the colonial secretary, expressed his desire for farmers to view it as a particular ally of theirs. ${ }^{73}$ But the SAC had serious problems of legitimacy. Set up after the annexation of the Boer republics by British imperialism, its policing role was immediately 
superseded by the military functions that it had to perform against the Boers once they shifted to the guerrilla phase of their struggle. Whatever the work the SAC engaged in after the war - such as helping to resettle Boers on their farms, ensuring that black tenants and servants were sufficiently subordinate to their landlords and masters - it was seen by the Boers as something of an army of occupation, one whose very uniform recalled that of the forces that had so recently destroyed the Boer states. ${ }^{74}$ British imperialists recognised its lack of legitimacy, one of them actually arguing that the Boers took the very size of the SAC as symbolic of a British fear of rebellion on their part, and Lord Milner himself mooting at one point that the force might be done away with as a sop to popular clamour. ${ }^{75}$ In the post-war period, then, the work of the SAC proceeded in an atmosphere of Boer suspicion. This was not helped by its being tasked to keep a watch - both openly, and through spies on Boer politics in the wake of the war. ${ }^{76}$

In fact, spying on Boer farmers played an important role in the collection of evidence in the Van Rensburg murder case. One of the SAC officers initially investigating the case, Sergeant J. Bullock he referred to himself simply as 'No. $X$ ' in his correspondence as an investigator - was infiltrated into the district as an agent of a firm specialising in 'Patent and Dutch Medicines' ${ }^{77}$ It is evident, too, that the SAC had the power to ensure that 'the Movements \& doings of the Visagies' were closely monitored, with even the specificity of a banking transaction discerned. ${ }^{78}$ They also clearly had a way into the inner world of Visagie's farm, because one officer was able to report on the helpfulness to the state case of 'a lot of home conversation between C. L. \& his wife'. Indeed, there is a cryptic comment in internal police correspondence which suggests that they had established some kind of intelligence network on the farm:

There is a rumour that the Police have been seen by Mrs. L. \& [also that she has seen] the bushmen [farm servants of Rooipoort were frequently referred to in this way] watching the house \& listening to conversations taking place in the evenings. I give the rumour for what it is worth, but of course think differently. ${ }^{79}$

What seems to be denied here is the rumour of Mrs Landman's knowledge, not the fact, of surveillance.

However, the strategy of utilising black people to procure evidence against whites on a farm at this time was likely to trigger fears arising from the recent war between Britain and the Boers: after all, it was said that Britain's intelligence operations against the Boers in the Transvaal during the conflict relied utterly on information provided by the region's black population. ${ }^{80}$ As we shall see, there were a number of ways in which the war-time role of the black rural population figured in the Van Rensburg trial, and they are likely to have accentuated the fears and prejudices of a white jury. But even before this jury was assembled, there was a more immediate problem for the SAC and the prosecution. For its case was struck by Cupid's arrow, and this led to some of the most damning evidence not being put forward at the murder trial. 
Sergeant Bullock had evidently fallen in love with Helena van Rensburg, the 18-year-old daughter of Landman's wife. Evidence provided both by Helena and her mother led a police superintendent to deduce that

since being connected with the case (known as the Volksrust murder) Detective Bullock has been on intimate terms with the girl, in fact ... had promised to marry her, which promise both mother and daughter were confidant [sic] he never intended to carry out. This matter and the worry and the matter of the murder had made the girl despondent, hence the threat [of suicide]. ${ }^{81}$

It may be that it was her mother who convinced Helena that Bullock was trifling with her. ${ }^{82}$ At any rate, Mrs Landman promptly brought the matter before a police superintendent. Now the idea that Helena was in Sergeant Bullock's thrall could be brought forward: this would have buttressed immensely the argument regarding Landman's stepdaughters that had been advanced by counsel for the defence at the preparatory examination - that 'the police were interfering with them, ${ }^{83}$ Sergeant Bullock himself admitted to the Criminal Investigation Department that it was 'quite true' that he had 'kept the girl ... as she had no means of support': he had 'bought her clothes and given her food', but his relationship with her was born 'more out of pity than anything else'. This, however, did not square with the fact that he had, as Bullock admitted, asked Helena's mother to 'consent to my marrying her'. The shrewd Mrs Landman informed him that her decision would have to await the end of the murder trial. ${ }^{84}$ The mother of Helena and Wilhelmina had found the lever to upset the case of the state. It was not long before Sergeant Bullock was subjected to a Board of Inquiry. Neither Helena nor Wilhelmina appeared at the murder trial and the state's case was thereby weakened. It can only be surmised that the police and the prosecution viewed the calling of them as threatening to divulge Bullock's unprofessional behaviour. Indeed, when the case was over and the police were trying to explain why a conviction had not been secured, they raised as a possible factor a loss of confidence by the Crown prosecution precisely because of the Bullock affair. ${ }^{85}$ And we should bear in mind that there was no neat separation of Crown prosecutor and police in this case: at the preparatory examination prior to the full murder trial, the prosecution was conducted by a police officer. ${ }^{86}$

Exposing what looked like the seduction of a witness, the giving of gifts and a promise of marriage to her would have shaken the standing of the SAC at the very time when Het Volk, the principal Boer party, was calling into question the need for its very existence. ${ }^{87}$ The SAC could proffer some of its most powerful evidence only by endangering the reputation of a constabulary that was meant to signal a new kind of policing in the Transvaal. It held back from this. It was bound by its own project and procedures. Its nervousness was such that it could - pedantically and, it seems, needlessly even question whether a particular officer should be taking an affidavit. ${ }^{88}$ How could it now expose itself publicly to an inability to keep the necessary distance between one of its officers and a key witness in a murder trial? Not surprisingly, Bullock - the man who had done so much to collect evidence from farm labourers and others - did not appear at that trial. When his name was mentioned by an accused as somebody trying to intimidate a witness, ${ }^{89}$ the prosecution must have winced at the possibility of what might have come out. As for the defence, they could leave the rest of their case to 
the immense power of the prejudice that insisted on the proper relationship of white masters and black servants.

Some of the servants who had earlier pointed to the presence and drinking of the accused on the day of the murder seemed to disappear. At any rate, they did not come before the Supreme Court when the case was held in $1905 .{ }^{90}$ Perhaps members of the Visagie family, still in control of the world of Rooipoort farm, had arranged this in some way. The strategy of the accused and their witnesses was now to rubbish as much as possible the evidence of the remaining black servants, even if this contradicted evidence given earlier. Thus Magdalena Visagie, wife of the accused Gil, denied that she had ordered the servant Velapi 'to fetch water' on the fateful night although this ran counter to the evidence that she had given at the inquest. ${ }^{91}$ Since Velapi had witnessed the holding down of Van Rensburg when she was returning with the water, it was obviously crucial now to deny that she had been sent to get water around the time of the murder. The police, it was asserted, were in cahoots with the servants. Martha van der Merwe, of one of the white tenant families on the farm, 'made rather a startling statement' before the court, 'when she said that the native Isaac had, on several occasions, told her that Sergeant Whelan had asked him to say that Gideon Visagie had murdered Van Rensburg, ${ }^{92}$ The idea that a black servant on the farm would be delivering such information over and over ('on several occasions') to a white woman strains credulity. We do know, however, that Isaac had engineered a different place for himself on the farm when he returned to it after the first investigation had collapsed. Martha van der Merwe's fantastic allegation emerged in such a context, and there can be no doubt that, as one of the witnesses for the defence, she was given to proposing the idea of police-servant collusion. This would have a very powerful effect on a jury at this time. Counsel for the defence must have been active in rubbing home its possibilities: hence, at the murder trial, Isaac was forced to deny that he 'told any white women that the police had offered him a big present if he would state that Gideon Visagie was the murderer'. ${ }^{93}$

The racial balance of testimony in the case was seen by the state as an Achilles' heel very early on. Long before the murder trial took place in Pretoria in May 1905, and even before the preparatory examination that preceded it in October-November 1904, a police Captain was warning that if Gil Visagie, the prime suspect, and his wife were 'utilised by the defence', the very fact of their 'being white witnesses could shake the native evidence badly'. ${ }^{94} \mathrm{His}$ instincts were right. The use of Africans, especially African servants, as witnesses against accused whites was something that would tend to scandalise a white jury in a colony. But there was a particular context in the early 20th century that would have made this particularly worrying for such a jury in the Transvaal. For a force associated with British imperialism, as the SAC was, to be mobilising black witnesses against white farmers would have recalled for the members of a Pretoria jury, most of whom were likely to have been Boers, some of the most unnerving and terrifying events of the recent South African War. For black servants and tenants had been used as witnesses against Boer farmers in treason trials, the outcome of which could be execution for the convicted. ${ }^{95}$ When it was intimated in court that a black witness was 'conspiring to have white men hung, ${ }^{96}$ this must have resonated with the results of black 
actions against the Boers during the South African War. Indeed, what might appear to be the most extravagant claims in court need to be read in their light. One of the white residents of Rooipoort declared that Isaac had told her that a policeman had 'promised to give him Visagie's farm' if he would declare that the landlord was the murderer. ${ }^{97}$ The idea that a policeman would be offering thousands of acres of land to a farm servant is, of course, ludicrous. But such an allegation needs to be read in terms of a recent war-time experience: the British sweeping of Boers off their farms, the role of black people in assisting them in this, and the subsequent taking over of Boer land in very many instances by the black peasantry. There was thus a certain logic in the defence witness's invention: it probably emerged from a consciousness shaped by the events of 1899-1902. There had, after all, been a recent expropriation of the Boers, and the British overlords of the Transvaal had to convince black peasants that the land they had appropriated from the Boers was not theirs. ${ }^{98}$

In short, given this history, convicting white men largely on the basis of black servant testimony in the early 20th century would have been something of a social and cultural violation for a Pretoria jury. And yet this is what the judge asked them to do: '[t]he case hinged on the evidence of the witnesses, Isaac and Filapi', he was reported as saying, 'and, if the jury believed their statements, they must find the accused guilty'. ${ }^{99}$ The authorities clearly thought that the judge believed Isaac's version of the events. ${ }^{100}$ Certainly he was open in stating 'that Isaac's story was detailed so minutely and in some respects corroborated the known facts of the case, that it was difficult to imagine that the boy had concocted the story all by himself'. ${ }^{101}$ (The detail was indeed extraordinary and included a description of Visagie returning to the place of the murder - this was relatively close to his own house - and striking matches in the darkness 'to see if there was any blood about'; it also included 'a practical demonstration' before the court - a bucket helpfully provided - of the mechanics of the killing. $)^{102}$

Justice Smith was clearly new to South Africa, describing himself as 'not very familiar with natives and the manner in which they gave evidence'. There were differences between Isaac's and Velapi's renderings of the tragic events, he noted, but 'he would not say that [as witnesses] they were absolutely irreconcilable'. Nevertheless, what was before the court was a case of rare difficulty, 'and if the jury had any doubt, they would have to give the accused the benefit of that doubt'. ${ }^{103}$ The jury retreated to make their decision. When they returned and found the men not guilty, the judge relayed his deep disquiet by announcing the verdict and offering no comment whatsoever, a point noted by both the police and the press. ${ }^{104}$ This might be taken as a signal that the judge disagreed with the verdict of a jury.

Gil Visagie, the baas of Rooipoort, could return to his long-suffering wife, his lover, his farm and its community, over all of which he was master. By the time of the trial, Velapi seems to have found a position with another white employer. ${ }^{105}$ As for Isaac, all we can be sure of is that he left the court to find some other place in the racial order of 20th-century South Africa. Rooipoort, the farm to whose master he had been given as a child, was now closed to him. The discovery there, in January 1903, of a poor white man with a slit throat and a hat over his face had set too much in train: a lowly servant's 
undermining of the power of his master and then the authorities' use of that servant in their quest to bring Baas Gil to the gallows.

What has this exercise in micro-history revealed of the early 20th-century colonial Transvaal? Most obviously, it has shed light on the texture of life and social hierarchy on Boer agrarian estates; it has also emphasised the degree to which race and master-servant relations shaped the operations and efficacy of the law. The case considered here also makes clear that, in this most transitional of societies, the social and economic power of the great landlord cascaded down the white and black classes below him. The poor white tenantry, often kinsfolk of the landowner and barely clinging on to rural livelihoods, were subject to his whims and power not merely in their access to land but in the matter of his personal desires - in this (admittedly extreme) instance, his desire for the murder of the husband of his lover. The evidence provided also alerts us to the need to recognise how Boer farmers, even into the 20th century, were benefiting not merely from the labour of white and black tenants settled on their lands, but also from the incorporation of those Africans, such as Isaac and Jacob on Rooipoort, who had originally been absorbed into Boer households and labour forces when they were powerless children. These were actual or social orphans, cut off from the families and communities whence they came. But however subordinate they were to the white farming families they served, they formed intimate ties with their masters: hence the confidence that the landowner had in Isaac's participation in the murder. But this intimacy on Rooipoort opened the way for what seems to have been an implicit blackmailing of the master once the police commenced their investigation into the murder. Only this can explain the transformation of Isaac's position on the farm prior to his being dragooned as a witness by the police.

This investigation of the world of the Van Rensburg murder has also emphasised the much more professional, far-reaching nature of policing in the Transvaal Colony compared with the police regime of the defeated South African Republic. It suggests as well the nervousness of the SAC in providing any ammunition that might be used against itself by the alienated and recently defeated Boers, who were, nevertheless, politically mobilised. Above all, the South African War - that great and reverberating conflict - shadowed this case. This would have given the idea of black servant testimony against whites such a potent resonance, recalling as it did wartime African intelligence against Boer forces, and also the black witnesses against landlords accused of treason. And it was the War, with the temporary expropriation of the Boers and the contestation of their rights to the land by black peasants, that must account for the hysterical allegation that the police had promised Rooipoort, Gil Visagie's farm, to the servant giving testimony against his master.

Finally, there is a more general point that is suggested by the micro-history that has been provided. We are familiar enough with how conditions of war and invasion can erode the power of masters on agrarian estates and allow those below them to express antagonisms otherwise held in check, even to the point of transforming social positions. ${ }^{106}$ The murder case explored here suggests that a drive against a particular master by legal authorities allows for something similar on a microcosmic scale in 
peacetime. Criminal cases against rural masters have the potential not only to illuminate but also to disrupt the relatively isolated, self-contained worlds commanded by landowners. And, as this article has demonstrated, as the police investigations and the law took their course, and as the servants were used in the drive against their master, the familiar relations of a rural order were jumbled and challenged, subjecting the landowner and his relatives to something of a social trauma.

\section{Notes}

1. Testimonies of Sgt-Major Whelan and Captain Fell, cited in Rand Daily Mail, 21 October 1904, p. 5, 'The Volksrust Murder'

2. No. X (Detective Sergeant Bullock: see note 77 below) to Lieut. McKensie, 24 July 1904 (citing findings of one who had explored the wound) in File Y/489/8: SAC (Archives of the Chief Staff Officer, South African Constabulary, 1900-1908), General Correspondence, Vol. 279. The SAC papers are part of the TAB (Transvaal Argief Bewaarplek/Transvaal Archives Depot) of the National Archives of South Africa, Pretoria/Tshwane. The dozens of SAC files referred to in this article are all from the General Correspondence section of the archive and part of its Vol. 279, which contains documentation from the period 1903-1905. In referring to these General Correspondence files hereafter, I will provide their reference numbers and dates and follow this simply with the designation 'SAC'.

3. For the fact of the knife being Van Rensburg's and Visagie placing it in the dead man's hand, see Isaac's testimony in The Star (Third Edition), 8 May 1905, p. 7, 'The Wakkerstroom Tragedy'; and Copy of sworn affidavit of 'ISAAC[,] a Native', 18 August 1904, p. 2 in File Y/489/17 dated 20 August 1904: SAC. (Hereafter Isaac's affidavit - which is referred to frequently in this article - will be referred to without the details regarding the archival source.) Van Rensburg's wife confirmed that the knife was her husband's: see evidence of Mrs van Rensburg in Rand Daily Mail, 27 October 1904, p. 5, 'Volksrust Murder'.

4. For evidence relating to the blood, see testimony of Hans, servant of Koos van der Merwe (one of Visagie's tenants) in Rand Daily Mail, 28 October 1904, p. 5, 'Volksrust Murder'; testimony of Sgt-Major Whelan in Rand Daily Mail, 21 October 1904, p. 5, 'The Volksrust Murder'; testimony of Sgt-Major Whelan in The Star (First Edition), 5 May 1905, p. 8, 'The Wakkerstroom Tragedy'. Quotations from Whelan's evidence in the Rand Daily Mail.

5. Giovanni Levi, 'On Microhistory', in Peter Burke (ed.), New Perspectives on Historical Writing (Cambridge, Polity Press, 1991), p. 109.

6. Carlo Ginzburg, 'Microhistory: Two or Three Things That I Know about It', Critical Inquiry, 20, 1 (1993), p. 20.

7. I refer here to Jeremy Krikler, Revolution from Above, Rebellion from Below: The Agrarian Transvaal at the Turn of the Century (Oxford, Clarendon Press, 1993).

8. For the quotations, see Ginsburg, 'Microhistory', p. 22; and Levi, 'On Microhistory', p. 95.

9. A drinking party of some kind is asserted not only by Jacob and Isaac - whose evidence is shortly to be cited - but also by a female servant, whose name is variously spelled as Vilapi, Velopie, Velopi and Filapi in the records and press. For her referring to the drinking of the men, see copy of sworn affidavit of Velopi, 13 September 1904, p. 1 (enclosure of No. X to Capt Hartigan, 14 September 1904) in File Y/489/27 dated 19 September 1904: SAC. See also the testimony of another servant, the 'native girl, Sarrah', in Rand Daily Mail, 1 November 1904, p. 7 , 'Volksrust Murder', who referred to all the accused as present.

10. Copy of sworn affidavit of 'Native Prisoner Jacob', 9 August 1904 (enclosure of No. X to Capt M. Hartigan, 11 August 1904) in File Y/489/13 [and] 14A, dated 12 August 1904: SAC. 
11. Copy of sworn affidavit of 'ISAAC[,] a Native', 18 August 1904, p. 2.

12. Ibid., pp. 2, 3.

13. Ibid., pp. 2-3; quotation from p. 3.

14. Evidence of Isaac, cited in Rand Daily Mail, 9 May 1905, p. 9, 'Pretoria Murder Trial'; and as cited in The Star (Third Edition), 8 May 1905, p. 7, 'The Wakkerstroom Tragedy'. Quotations from Rand Daily Mail.

15. For the nature of black tenants and servants on white-owned farms, as well as a sense of the nature of the black peasantry on communal land, in the late 19th and early 20th centuries, see Krikler Revolution from Above, pp. 4-9 and Chapter 4.

16. Copy of sworn affidavit of 'ISAAC[,] a Native', 18 August 1904, p. 1.

17. He spoke in 1905 of having worked for Visagie for a decade: see testimony of Isaac in The Star (Third Edition), 8 May 1905, 'The Wakkerstroom Tragedy'. But in 1904 he gave his age as 'about twenty one years old' and spoke of having been 'a small boy' when he arrived at Visagie's farm: see Copy of sworn affidavit of 'ISAAC[,] a Native', 18 August 1904, p. 1. This suggests that he fell under Visagie in the early 1890s.

18. For the origins, conditions and transformation of this class, see Peter Delius and Stanley Trapido, 'Inboekselings and Oorlams: The Creation and Transformation of a Servile Class', in Belinda Bozzoli (ed.), Town and Countryside in the Transvaal: Capitalist Penetration and Popular Response (Johannesburg, Ravan Press, 1983), esp. pp. 61, 64-78.

19. Ibid., p. 75 .

20. Documentation relating to this - some of it has it be interrogated very carefully, particularly if it relates to farmers' responses to the police (or to a worker's response to the police, apparently in the presence of, or with the knowledge of, an employer ) - can be found in File 627/1909 titled 'Picannins recruited by Ross' Agency apparently "sold" to farmers' (a file itself placed in File 2254/13/53 titled 'Miscellaneous Files re boys for Domestic \& other Service') in GNLB (Archives of the Director of the Government Native Labour Bureau), Correspondence, Vol. 126. (The GNLB Archives are housed at the South African National Archives in Pretoria/Tshwane). For the concerns referred to in the text, see W.A. Terry (a labour inspector) to O/C Police, Nigel, 27 January 1909 and 2 February 1909; W.A. Terry to Native Commissioner Heidelberg, 1 February 1909; W.A. Terry to Director GNLB, 2 February 1909 and 5 February 1909. All quotations from Terry, who, in using the word 'bought', appears to be citing farmers.

21. Copy of sworn affidavit of 'ISAAC[,] a Native', 18 August 1904, p. 4.

22. Copy of sworn affidavit of 'Native Prisoner Jacob', 9 August 1904 (enclosure of No. X to Capt. M. Hartigan, 11 August 1904) in File Y/489/13 [and] 14A dated 12 August 1904: SAC.

23. Such servants took their place among the black retainers or agterryers of the Boer forces. For the agterryers generally, see the analysis of them in Fransjohan Pretorius, Life on Commando during the Anglo-Boer War (Cape Town, Human and Rousseau, 1999); Pieter Labuschagne, Ghostriders of the Anglo-Boer War (1899-1902): The Role and Contribution of Agterryers (Pretoria, Unisa Press, 1999); and Bill Nasson, Abraham Esau's War:A Black South African War in the Cape, 1899-1902 (Cambridge, Cambridge University Press, 1991), pp. 94-5, 96-102, $128,152,161$. For the place of the trusted and acculturated servant from the Boer republics in agterryer ranks, see pp. 98-100.

24. See testimony of Isaac in The Star (Third Edition), 8 May 1905, 'The Wakkerstroom Tragedy'.

25. Quotation from No. X to Capt. Hartigan, 13 September 1904 in File Y/489/25 [and] 26 dated 14 September 1904: SAC. 
26. Copy of affidavit of Velopi, 13 September 1904: enclosure of No. $X$ to Captain Hartigan, 14 September 1904 in File Y/489/27 dated 19 September 1904: SAC. See also testimony of Filapi in The Star (Third Edition), 6 May 1905, p. 8, 'The Wakkerstroom Tragedy'.

27. For this last fact, see No. $X$ to Capt. Hartigan, 24 July 1904 in File Y/489/8: SAC. The reference is to Isaac having been 'sent away or left'. Being a servant, however, he could not have left of his own volition.

28. All of this information comes from, respectively, No. X to Lieut McKensie, 24 July 1904 in File Y/489/8 dated 26 July 1904; No. X to Capt. Hartigan, 5 August 1904 in File Y/489/11 [and] 12 dated 8 August 1904; and No. X to Capt. Hartigan, 24 July 1904 in File Y489/8 dated 26 July 1904. All files are in SAC. Note: references to Hans and to 'Landman's Boy' in some of this documentation are references to black farm workers on 'Rooipont'.

29. Two susbstantial state commissions of the early 20th century dealt with the questions, respectively, of the scarcity of black labour and white poverty. See Transvaal Labour Commission. Report of the Transvaal Labour Commission: Together with Minority Report, Minutes of Proceedings and Evidence (Johannesburg, 1903-4); and Report of the Transvaal Indigency Commission, 1906-1908 (1908).

30. See testimony of Mathys [incorrectly called Natthys] Grove in Rand Daily Mail, 22 October 1904, p. 10, 'The Volksrust Murder'.

31. See Copy of sworn affidavit of 'Native Prisoner Jacob', 9 August 1904 (enclosure of No. X to Capt. M. Hartigan, 11 August 1904) in File Y/489/13 [and] 14A dated 12 August 1904: SAC. My research suggests that there may have been some errors or incompleteness in Jacob's rendition, but it is the fact of his referring to whites 'working for Gil Visagie' that is significant here.

32. See William Macmillan, The South African Agrarian Problem and its Historical Development (Reprint No. 68 of the State Library, Pretoria, 1974 [1919]) where these various points emerge or are implied.

33. Evidence of one McDulling, relative of Visagie, in Rand Daily Mail, 21 October 1904, p. 5, 'The Volksrust Murder'.

34. Evidence of Hendrik Visagie in Rand Daily Mail, 26 October 1904, p. 5, 'Volksrust Murder'.

35. For the quotations relating to Hans, see point 10 of No. $X$ to Capt. Hartigan, 3 November 1904; and No. V to Capt. Hartigan, 3 November 1904 in File Y/489/43 [and] 44: SAC.

36. Testimony of Wilhelmina van Rensburg, Landman's stepdaughter, in Rand Daily Mail, 25 October, 1904, p. 9, 'Volksrust Murder'. The evidence regarding the money appears confirmed by Wilhelmina's sister, Helena: see her testimony as cited in the same source.

37. Testimony (including under cross-examination) of Hendrik Visagie (brother of the accused Gideon) in Rand Daily Mail, 26 October 1904, p. 5. It should be noted that, in this evidence, it also emerged that Hendrik had lent Landman $£ 30$, money that was repaid, most of it quite quickly. This money, however, would appear to have been distinct from that associated with the spree referred to in the text, though it is possible that the sums were mingled. The important point to bear in mind is Landman's ability to offer something of a down payment on a farm immediately after the murder and the hint that this was related to meeting Gideon for a 'spree' in Volksrust.

38. Copy of sworn affidavit of 'ISAAC[,] a Native', 18 August 1904, p. 4.

39. See evidence of Willem in Rand Daily Mail, 28 October 1904, p. 5, 'Volksrust Murder'.

40. For the stealing of the pigs, see copy of statement of Constable Christoffel Delport, 30 June 1904 in File Y/489/1 dated 28 June 1904: SAC. For Hans' view and the cousin giving evidence, see 
testimony of McDulling (he referred to a conversation with Hans, i.e. C.J., Visagie) in Rand Daily Mail, 21 October 1904, p. 5, 'The Volksrust Murder'.

41. For the last fact, see testimony of Johanna Grant in The Star (Third Ed.), 5 May 1905, p. 8, 'The Wakkerstrom Tragedy'.

42. Testimonies of Wilhelmina van Rensburg and Mrs Van Rooyen (both residents of the Volksrust camp) in Rand Daily Mail, 25 October 1904, p. 9, 'Volksrust Murder'; testimony of Kitigeta, a servant who had worked in the camp, in Rand Daily Mail, 27 October 1904, p. 5; testimony of Mrs Joubert, a neighbour of Mrs van Rensburg in Volksrust, in Rand Daily Mail, 1 November 1904, p. 7, 'Volksrust Murder'.

43. See testimony of Frans Parsons (who conversed with Visagie) in Rand Daily Mail, 27 October 1904, p. 5, 'Volksrust Murder'.

44. Evidence of Sgt-Major Whelan, Rand Daily Mail, 21 October 1904, p. 5, 'The Volksrust Murder'.

45. See S. Swart, 'A Boer and his Gun and his Wife are Three Things Always Together', Journal of Southern African Studies, 24, 4 (1998), p. 742.

46. For the promissory note, see, for example, the abbreviated reference in point 3 of No. X to Capt. Hartigan, 3 November 1904 in File Y/489/43 [and] 44 dated 5 November 1904: SAC. For the quotation and what came to van Rensburg's widow, see testimony of Mrs van Rensburg in Rand Daily Mail, 27 October 1904, p. 5, 'Volksrust Murder'.

47. See No. $X$ to Capt. Hartigan, 3 November 1904, point 3, in File $Y / 489 / 43$ [and] 44 dated 5 November 1904: SAC; and testimony of Willem in Rand Daily Mail, 29 October 1904, p. 8 , 'Volksrust Murder'.

48. Passage based on testimonies of Ger[h?]ardus Visagie (van Rensburg's brother-in-law) and Hendrik Visagie (brother of Gil and Hans) in Rand Daily Mail, 26 October 1904, p. 5, 'Volksrust Murder'; testimony of Johanna Grant, daughter of one of the white tenants on 'Rooipoort', in Rand Daily Mail, 22 October 1904, p. 10, 'The Volksrust Murder'; and evidence of McDulling, farmer and relative of Visagie, in Rand Daily Mail, 21 October 1904, p. 5, 'The Volksrust Murder'. Quotation from Gerhardus Visagie.

49. See Irving Hexham, The Irony of Apartheid: The Struggle for National Independence of Afrikaner Calvinism against British Imperialism (Lewiston, Edwin Mellen Press, 1981), pp. 74, 77.

50. I have woven this analysis of the servants' knowledge from particular testimonies in the Rand Daily Mail, which always appeared in articles under the same title - 'Volskrust Murder'. See evidence of an unnamed 'native in the employ of Gideon Visagie' (2 November 1904, p. 7); one Willem, certainly a servant of some kind (29 October 1904, p. 8); Rose (1 November 1904, p. 7); and Clara (1 November 1904, p. 7).

51. 51 Copy of sworn affidavit of 'ISAAC[,] a Native', 18 August 1904, p. 6. Isaac, however, appears to have misdated the fight as taking place on the day of the murder. It evidently took place earlier: see testimony of Ger[h]ardus Visagie, brother-in-law of the murdered man, in Rand Daily Mail, 26 October 1904, p. 5, 'Volksrust Murder'.

52. This last point is implied by Lieut Atwater's objection as cited in Rand Daily Mail, 21 October 1904, p. 5, 'The Volksrust Murder'.

53. This is suggested by the testimony of Willem Gissing (in conjunction with that of Theodorus van der Merwe) cited in The Star (Third Edition), 9 May 1905, p. 12, 'The Wakkerstroom Tragedy'.

54. No. X to Capt. Hartigan, 5 August 1904 in File Y/489/11 [and] 12 dated 8 August 1904): SAC. 
55. No. $X$ to Capt. Hartigan, 13 September 1904, in File $Y / 489 / 25$ [and] 26 dated 14 September 1904; and No. X. to Capt. Hartigan, 14 September 1904 in File Y/489/27 dated 19 September 1904: both files in SAC.

56. For view of defending counsel, see No. $X$ to Capt. Hartigan, 26 October 1904 in File $Y / 489 / 38$ dated 27 October 1904: SAC. For the police view, see No. V to Capt. Hartigan, no date, in File Y/489/41 dated 1 November 1904: SAC.

57. Archival snippets apparently relating to the case are SPR 625/91 and SPR 750/91 - these are telegrams from 1891 - and can be found in SP (Suid-Afrikaanse Republiek: Argief van de Staatsprokureur/South African Republic: Archives of the State Attorney), Minutes, Vol. 25. (The SP records are held at the National Archives of South Africa in Pretoria/Tshwane.) I identified the following documents as seemingly related to this case: SPR 330/91, SPR 358/91, SPR 448/91, SPR 449/91, SPR 519/91. They are supposed to be in SP, Minutes, Vol. 24, but appear to have been removed from the volume. For a basic sketch of the earlier murder and trial, see No. X to Capt. Hartigan, 27 June 1904 in File Y/489/1 dated 28 June 1904: SAC.

58. Copy of sworn affidavit of Helena van Rensburg, 27 September 1904: enclosure of Chief Staff Officer SAC to Sec. to the Law Department, 6 October 1904 in File Y/489/29, [and] 32 dated 3 October 1904: SAC.

59. This was the view of Landman's stepdaughter, as stated in Cottrell to 'B' [Bullock], no date except 'Sunday' (enclosure of No. X to Capt. Hartigan, 18 September 1904) in File Y/489/28 dated 20 September 1904: SAC.

60. See the document from Cottrell in ibid.

61. Evidence of Wilhelmina van Rensburg, reported in Rand Daily Mail, 25 October 1904, p. 9, 'Volksrust Murder'.

62. See Rand Daily Mail, 26 October 1904, p. 5, 'Volksrust Murder'.

63. Information in this sentence is based on Supt B Betts to Inspector of Police, 9 March 1905; the tenor of a letter (evidently from Wilhelmina to Helena van Rensburg) in Dutch (with translated version) dated 15 April 1905; and J.B. Bullock to C.D.I. [sic], 11 March 1905. All documents in File 1218/05 entitled 'Rex versus Landman and others: Murder. Statement of Miss van Rensburg' in LD (Archives of the Secretary of the Law Department, 1900-25), Correspondence, Vol. 1036. The LD Archives are held in the National Archives of South Africa in Tshwane/Pretoria.

64. Testimony under cross-examination of Helena van Rensburg in Rand Daily Mail, 25 October 1904, p. 9, 'Volksrust Murder'.

65. Copy of sworn statement of Wilhelmina van Rensburg dated 12 November 1904 in File 1218/05 entitled 'Rex versus Landman and others: Murder. Statement of Miss van Rensburg' in LD, Vol. 1036.

66. However, the scene in McQueen's film where Solomon Northrup is left dangling does not correspond with the description provided in the autobiography: see Solomon Northrup, Twelve Years A Slave (New York, Derby and Miller, 1853; illus. edn, S. Eakin and J. Logsdon [eds], Baton Rouge, Louisiana State University Press, 1968), Chapter 9.

67. See Nigel Worden, Slavery in Dutch South Africa (Cambridge, Cambridge University Press, 1985), p. 117. For an example, see Robert Shell, Children of Bondage: A Social History of the Slave Society at the Cape of Good Hope, 1652-1838 (Hanover, Wesleyan University Press, 1994), p. 265.

68. See typescript copies of sworn affidavits of Wilhelmina and Helena van Rensburg dated 12 November 1904 in File 1218/05 titled 'Rex versus Landman and others: Murder. Statement of Miss van Rensburg' in LD, Vol. 1036. Quotations from Helena's affidavit. 
69. Copy of affidavit of Wilhelmina van Rensburg, 7 April 1905 in ibid. Wilhelmina's evidence pertains also to Helena's threat to take poison.

70. See Charles van Onselen, Studies in the Social and Economic History of the Witwatersrand 1886-1914, Volume I, New Babylon (Johannesburg, Longman, 1982), pp. 61, 62, 65-6, 81, 105; and Albert Grundlingh, "'Protectors and friends of the people"? The South African Constabulary in the Transvaal and Orange River Colony, 1900-1908', in David Anderson and David Killingray (eds), Policing the Empire. Government, Authority and Control, 1830-1940 (Manchester, Manchester University Press,1991), p. 179.

71. See J.A. Hobson, The War in South Africa: Its Causes and Effects (London, 1900), pp. 52-3, 54, $55,56-7$, and $57-8 \mathrm{n}$ for the contemporary debunking of this propaganda.

72. Grundlingh, '"Protectors and friends of the people"?', p. 179

73. Ibid., pp. 169, 170; and (for Chamberlain) Krikler, Revolution From Above, p. 47.

74. My passage rests on the findings of Grundlingh, '"Protectors and friends of the people"?'

75. Donald Denoon, A Grand Illusion: The Failure of Imperial Policy in the Transvaal Colony during the Period of Reconstruction 1900-1905 (London, Longman, 1973), pp. 207, 213.

76. Grundlingh, '"Protectors and friends of the people"?', p. 173.

77. This is suggested by No. $X$ to Capt. Hartigan, 24 June 1904 and enclosure (the printed card of the firm, L. Gerschuny, referred to, with J. Bullock written on the card by hand): in File Y/489 dated 25 June 1904: SAC. That Bullock was No. $X$ is further confirmed by comparing the handwriting of letters signed by No. $X$ with the handwriting of a letter that we know is from Detective Sergeant Bullock (that of 23 December 1904, to be found in File Y/489/59 dated 22 December 1904: SAC). The quotation is from the card referred to.

78. No. X to Capt. Hartigan, 30 August 1904 in File Y/489/22 dated 1 September 1904: SAC.

79. Cottrell to 'B' (Bullock), no date except 'Sunday' (enclosure of No. $X$ to Captain Hartigan, 18 September 1904) in File Y/489/28 dated 20 Sept. 1904: SAC.

80. Krikler, Revolution From Above, pp. 10-11.

81. Supt B Betts to Inspector of Police, 9 March 1905 in File 1218/05 entitled 'Rex versus Landman and others: Murder. Statement of Miss van Rensburg': LD, VOL. 1036.

82. See evidence in Copy of affidavit of Wilhelmina van Rensburg, 7 April 1905 in ibid.

83. As argued by Dr van Gelder: see Rand Daily Mail, 26 October 1904, p. 5, 'Volksrust Murder'.

84. See J.B. Bullock to C.D.I. [sic], 11 March 1905 in File 1218/05 titled 'Rex versus Landman and others: Murder. Statement of Miss van Rensburg': LD, VOL. 1036.

85. For this fact and a reference to Bullock's Board of Inquiry, see 'Notes' by S.O. 2 dated 11 May 1905 on File Y/489/84 dated 11 May 1905: SAC.

86. The was Lt Atwater - see Rand Daily Mail, 21 October 1904, p. 5, 'The Volksrust Murder'. As a number of my footnotes imply, he was a member of the South African Constabulary.

87. See De Volkstem, 3 May 1905, p. 6, reporting on a communiqué from the party's leading body.

88. See copy of Lt-Col. R.S. Curtis to Divisional Commandant (Northern Transvaal), 24 March 1905; copy of Col. Steele to Chief Staff Officer, South African Constabulary, 25 March 1905; and Acting Secretary to the Law Department to Chief Staff Officer, South African Constabulary, 14 April 
1905. All documents are in File AG 1218/05 titled 'Rex versus Landman and others: Murder': LD, VOL. 1036.

89. See testimony of Johan Carl Landman in The Star (Third Ed.), 9 May 1905, p. 12, 'The Wakkerstroom Tragedy' (sub-section 'The Defence').

90. This is true of Sarrah and Jacob, who had given evidence the preceding year, as noted earlier in this article. I have found no reference to evidence from them in the press coverage of the 1905 case. Their names also do not appear in the Supreme Court witness list for that trial. See Supreme Court. Calendar of Cases to be tried at the Criminal Sessions of the Supreme Court to be Holden at Pretoria on the 20th Day of April, 1905 (Attorney-General's Office, Pretoria, 14 April 1905), pp.12-13: LD, Vol. 600.

91. Testimony of Magdalena Visagie in The Star, 9 May 1905 (Third Ed.), p. 12, 'The Wakkerstroom Tragedy'.

92. Testimony of Martha van der Merwe in Rand Daily Mail, 10 May 1905, p. 5, 'Wakkerstroom Murder'.

93. Testimony of Isaac in The Star (Third Ed.), 8 May 1905, p. 7, 'The Wakkerstroom Tragedy'.

94. Captain [Hartigan?] to No. X, 25 August 1904 in File Y/489/19-20 dated 25 August 1904: SAC. The husband and wife are referred to as 'the Rooipoorts' in this letter. Gideon (or Gil) Visagie was referred to in such a way because 'there are so many Visagies in the district': see No. $X$ to Capt. Hartigan, 30 August 1904 in File Y/489/22 dated 1 September 1904: SAC. In the course of my research, I have come across multiple spellings of the appellation: Rooipoort, Rooiport. Rooipont. It appears that the designation of Gideon Visagie in this way derived from the name of his farm, which was sometimes erroneously called 'Roodepoort'.

95. For this and its wider context, see Nasson, Abraham Esau's War, Chapter 8.

96. See cross-examination of Hans, employee of one of Visagie's tenants, in Rand Daily Mail, 28 October 1904, p. 5, 'Volksrust Murder'.

97. Testimony of Martha van der Merwe in The Star (Reef Ed.),10 May 1905, 'The Wakkerstroom Tragedy'.

98. For the dramatic impact of the war on land and agrarian social relations more generally, and the British campaign to restore the power of landlords and masters, see Krikler, Revolution From Above, Chapters 1 and 2.

99. 'The Summing Up' (part of 'The Wakkerstroom Tragedy') in The Star (Third Ed.), 10 May 1905.

100. See 'Notes' by S.O. 2 dated 11 May 1905 on File Y/489/84 dated 11 May 1905: SAC.

101. See 'The Summing Up' (part of 'The Wakkerstroom Tragedy') in The Star (Third Ed.), 10 May 1905.

102. See Isaac's testimony in The Star (Third Ed.), 8 May 1905, p. 7, 'The Wakkerstroom Tragedy'.

103. See 'The Summing Up' (part of 'The Wakkerstroom Tragedy') in The Star (Third Ed.), 10 May 1905.

104. See comment by S.O. 2 dated 11 May 1905 on File Y/489/84 dated 11 May 1905: SAC; and 'Verdict: "Not Guilty"' (sub-section of 'The Wakkerstroom Tragedy') in The Star (Third Ed.), 10 May 1905.

105. See Filapi's testimony in The Star (Third Ed.), 6 May 1905, 'The Wakkerstroom Tragedy'. 
106. Eric Foner long ago provided some wonderful examples of this from the American Civil War: see his Reconstruction: America's Unfinished Revolution, 1873-1877 (New York, HarperCollins, 1989), pp. 3-4, 51. 